\title{
Corrigendum: RIPK3: A New Player in Renal Fibrosis
}

\author{
Ying Shi ${ }^{1 *}$, Xinming Chen ${ }^{2}$, Chunling Huang ${ }^{2}$ and Carol Pollock ${ }^{2 *}$ \\ ${ }^{1}$ Department of Nephrology, School of Medicine, Stanford University, Palo Alto, CA, United States, ${ }^{2}$ Kolling Institute of \\ Medical Research, Sydney Medical School, The University of Sydney, Sydney, NSW, Australia
}

Keywords: RIPK3, receptor interacting serine/threonine-protein kinase 3 , renal fibrosis, TGF- $\beta 1$, necroptosis, dabrafenib

\section{A Corrigendum on}

\section{OPEN ACCESS}

Edited and reviewed by:

Frontiers in Cell and Developmental Biology Editorial Office,

Frontiers Media SA, Switzerland

*Correspondence:

Ying Shi

yshi6125@stanford.edu yshi6125@uni.sydney.edu.au

Carol Pollock

carol.pollock@sydney.edu.au

Specialty section:

This article was submitted to

Signaling,

a section of the journa

Frontiers in Cell and Developmental

Biology

Received: 22 April 2021

Accepted: 18 May 2021

Published: 09 June 2021

Citation:

Shi Y, Chen X, Huang $C$ and Pollock $C$ (2021) Corrigendum: RIPK3: A New

Player in Renal Fibrosis. Front. Cell Dev. Biol. 9:699073. doi: 10.3389/fcell.2021.699073

\section{RIPK3: A New Player in Renal Fibrosis}

by Shi Y, Chen X, Huang $C$ and Pollock C (2020). Front. Cell Dev. Biol. 8:502. doi: $10.3389 /$ fcell.2020.00502

In the original article, there was a mistake in the legend for Figure $\mathbf{1}$ as published. We neglected to include that Figure $\mathbf{1}$ was created with BioRender.com. The correct legend appears below.

Figure 1. RIPK3 and TGF- $\beta 1$. TGF- $\beta 1$ exhibits its biological function via the canonical Smad/non-Smad pathways or TAK1/necrosome/AKT/ACL signaling to mediate ECM accumulation and fibroblast activation. Necroptosis or RIPK3 facilitates NLRP3 inflammasome assembly, triggers mature IL- $1 \beta$ secretion, and promotes the TGF- $\beta 1$ transcription via the IL- $1 \beta$ regulated AP- 1 and NFKB pathway (Lee et al., 2006). IL-1 $\beta$, TGF- $\beta$, and TLR signaling pathways all activate TAK1 and its regulated inflammatory mediators (Kim and Choi, 2012; Fechtner et al., 2017). RIPK3, Receptor-interacting serine/threonine-protein kinase 3; TGF- $\beta 1$, transforming growth factor beta-1; TAK1, TGF- $\beta$-activated kinase 1; AKT, protein kinase B; ACL, ATP citrate lyase; ECM, extracellular matrix; TLR4, toll-like receptor 4; LPS, lipopolysaccharides; NLRP3, NOD-, LRR- and pyrin domain-containing protein 3; IL-1 $\beta$, interleukin-1 $\beta$; AP-1, activator protein $1 ; \mathrm{NF} \kappa \mathrm{B}$, nuclear factor-kappa B. Created with BioRender.com.

The authors apologize for this error and state that this does not change the scientific conclusions of the article in any way. The original article has been updated.

Copyright $\odot 2021$ Shi, Chen, Huang and Pollock. This is an open-access article distributed under the terms of the Creative Commons Attribution License (CC BY). The use, distribution or reproduction in other forums is permitted, provided the original author(s) and the copyright owner(s) are credited and that the original publication in this journal is cited, in accordance with accepted academic practice. No use, distribution or reproduction is permitted which does not comply with these terms. 